\title{
An Experimental Study on the Evaluation of Fastening Unit Insulation Developed for the Insulation of Curtain Wall
}

\author{
Kim, Bong-Joo* Kim, Kyeong-A \\ ConDepartment of Architectural Engineering, KongJu National University, KongJu, 314-701, Korea
}

\begin{abstract}
This study is the experimental study to improve the insulation of the fastening unit system, which has the most vulnerable insulation in the curtain walls. The Fastening Units were designed and fabricated to minimize the connection part of mullions. In addition, slight movements were taken into account and the performance of the middle layer was evaluated by forming an insulation layer with the vibration-proof rubber and the silicon to satisfy the mechanical and thermal performance criteria. A total of 10 experiments were performed under various conditions, such as indoor-outdoor temperature difference, type of insulation material, thickness of insulation material, and others. using the fabricated Fastening Units. As a result, the vibration-proof rubber insulation showed the temperature difference of 2 . $2^{\circ} \mathrm{C}-5.0^{\circ} \mathrm{C}$, and the silicon insulation showed the temperature difference of $2.8^{\circ} \mathrm{C}-4.5^{\circ} \mathrm{C}$, compared to the non-insulated Fasteniirature difference, typesng Units. When these results were compared with the psychometric chart graph, the insulated Fastening Unit designed in this study can be considered to prevent the dew condensation.
\end{abstract}

Keywords : curtain wall, insulation fastening unit, thermal bridge, condensation, dew point temperature

\section{Introduction}

\subsection{Study objective}

As high-rise buildings and various designs for buildings have recently been in high demand, the demand for curtain walls has also been on the rise. In recent years, the government has enforced diverse energy-saving policies for building structures, and to keep up with the trend, the construction industry has tried to introduce effective insulation technologies for the curtain wall. However, condensation due to thermal bridge between the mullion part and fastening unit has an adverse influence on the building, including the

Received : September 30, 2011

Revision received : December 30, 2011

Accepted : February 17, 2012

* Corresponding author: Kim, Bong-Joo

[Tel: 82-41-521-9334, E-mail: bingma@kongju.ac.kr]

(c)2012 The Korea Institute of Building Construction, All rights reserved. generation of rust and mold on the steel construction[1,2]. For this reason, both heat loss and condensation have been identified as the main problems of the curtain wall due to insufficient consideration of the effect of these factors on conventional buildings[3].

The fastening unit system used in the curtain wall generally consists of slab embedded $\mathrm{C}$-channel, fastener, $\mathrm{T}$ bolt and nut, most of which are made of steel. The thermal conductivity of steel is $45.3 \mathrm{~W} / \mathrm{m}^{\circ} \mathrm{C}$, which is very high and vulnerable to condensation[4]. The mullion that is connected to the fastening unit consists of steel or aluminum (thermal conductivity: $221.0 \mathrm{~W} / \mathrm{m}^{\circ} \mathrm{C}$ ). This is the part where thermal bridge of curtain wall occurs, and heat loss increases. This is also where condensation occurs in winter, which causes the rusting of steel, and the decay and elimination of the fire-resistant materials between floors. 
Moreover, the plated zinc is likely to come off during connection, construction, and transportation, so the concern of corrosion cannot be eliminated completely. Especially, in case of aluminum, there can be an adherend with the high-alkali concrete, and when condensation occurs the alkali is likely to corrode the aluminum. For these reasons, insulation is absolutely required for fastening units, and studies have been carried out on the insertion of urethane between the fastening unit parts, and on coating the fastening unit using the insulation paint or urethane foam[4,5,6]. However, the experimental findings cannot be practically used on a construction site, because only a simulation experiment was done instead of using an actually manufactured prototype. In addition, the strength measurement of the urethane inserted between the parts of the fastening unit and the degree of rust caused by the condensation were not clearly understood. Therefore, this research aims to evaluate the insulation performance of the fastening unit designed in a research project to develop parts and materials for multi-functional panel systems that has used the fire-resistant, lightweight inorganic composite foam material as a curtain wall material.

\subsection{Study method and scope}

The current fastening unit system had a large thermal bridge due to the connection of the curtain wall and the bracket with a wide area. If the connected area is not reduced, it is hard to prevent partial condensation, and even though the mullion is insulated in the middle using azon, the full effect of this insulation cannot be expected[7,8].

Thus, based on this a fastening unit system was developed in this study in order to insulate the fastening unit. Unlike typical fastening units, the thermal bridge was reduced by minimizing the connecting area between the primary and the secondary unit for insulation. In addition, to endure the structural movement of the building, the lower parts of the components that connects the primary and secondary units by axis, were designed to be round (see Figures 1 and 2). As insulation materials suitable for the developed fastening unit system, vibration-proof rubber and silicon were selected to evaluate their insulation properties. Figure 1 shows the components of the fastening unit, and Figure 2 shows the assembled product.

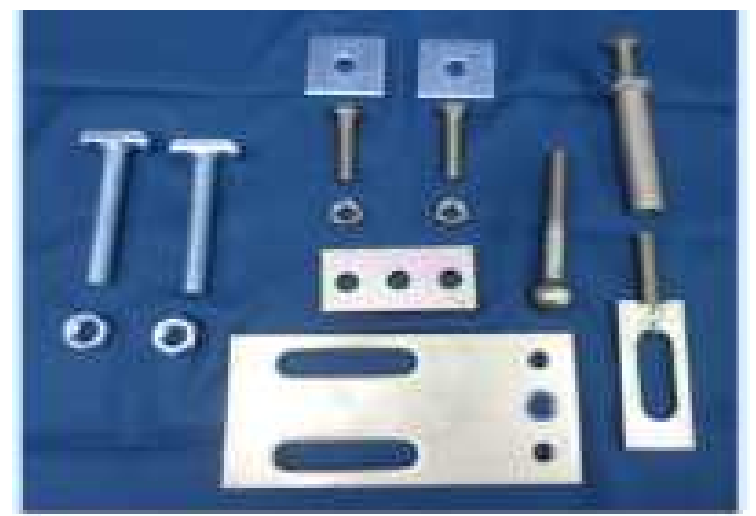

Figure 1. Components of fastening unit

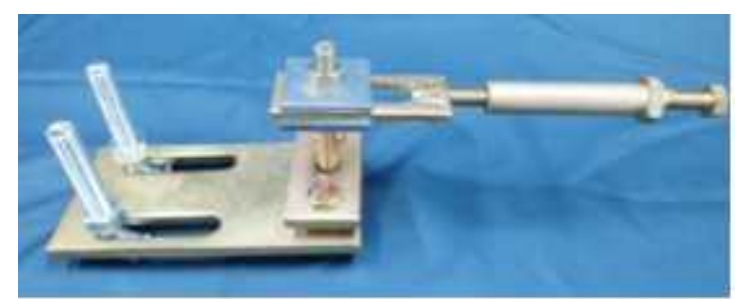

Figure 2. Assembled state of the developed fastening unit

\section{Previous studies}

Currently, previous studies and field applications related to the insulation of the curtain wall, windows and doors have been on the rise. However, there have been very few studies and 
applications related to the insulation of the fastening unit. The insulation of the fastening unit is rarely applied in the field, and there are only a few previous studies related to the insulation of the fastening unit. The contents of the previous studies related to the insulation of the fastening unit, will be dealt in this study.

\subsection{Insertion of the insulation material}

To block the heat transfer path which starts from the outdoor air and continues to the fastening unit and to the slab, two methods were contrived. One is to insert the insulation washer and the insulation pad inside the fastening unit itself, and the other is to insert the coated component in the interlayer which is the area between the fastening unit and the finishing material. The experimental conditions of the inserted insulation materials are shown in Table $1[5]$.

Table 1. Inserted insulation materials

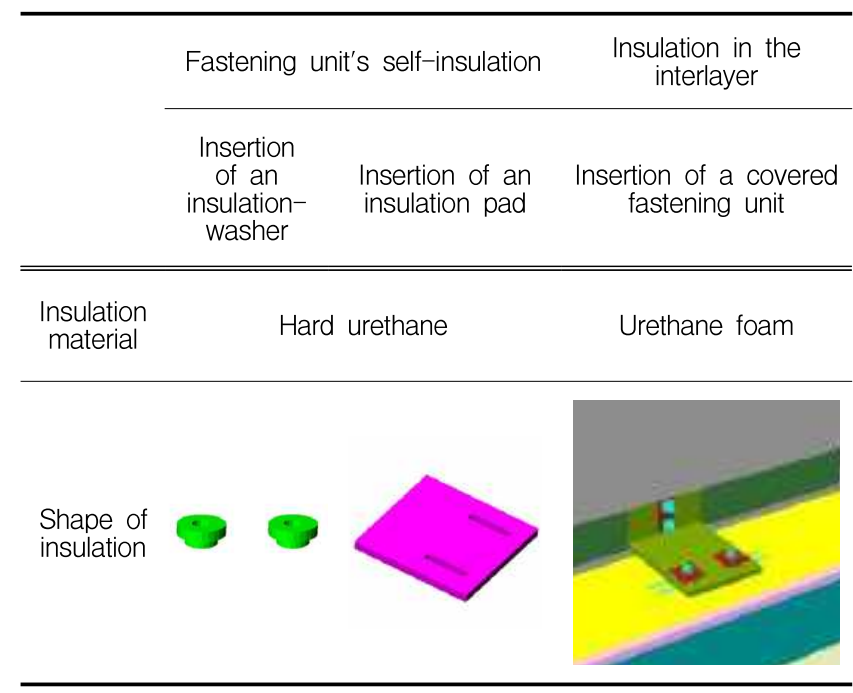

The simulation result, based on the experimental conditions in Table 1, showed that inserting the insulation washer and the insulation pad inside the fastening unit itself resulted in the least heat loss. The simulation results of the insulation material inserted fastening unit are compared in Table 2, based on the annual heat loss of the non-insulated fastening unit.

Table 2. Comparison of heat loss (Inserted)

\begin{tabular}{ccc}
\hline Insulation type & $\begin{array}{c}\text { Heat Losses Per } \\
\text { Year }(\mathrm{J})\end{array}$ & $\begin{array}{c}\text { Comparison with } \\
\text { Non-insulated (\%) }\end{array}$ \\
\hline Non-insulation & $495,024,435$ & - \\
$\begin{array}{c}\text { Insertion of an } \\
\text { insulation-washer }\end{array}$ & $494,206,290$ & -0.17 \\
$\begin{array}{c}\text { Insertion of an } \\
\text { insulation pad }\end{array}$ & $485,995,671$ & -1.82 \\
$\begin{array}{c}\text { Insertion of a } \\
\text { covered fastening } \\
\text { unit }\end{array}$ & $478,219,212$ & -3.40 \\
\hline
\end{tabular}

\subsection{Covering with the insulation material}

This study is experimented by covering the fastener of the fastening unit with the insulation material, considering that the thermal conductivity of the steel used as the components of the fastening unit, is very high at $45.3 \mathrm{~W} / \mathrm{m}^{\circ} \mathrm{C}$. Three types of covering method were contrived for evaluation: insulation paint covering, urethane foam covering, insulation paint + urethane foam complex covering. The conditions used to evaluate the covered fastener are shown in Table $3[4,6]$.

Table 3. The fastening unit covered with the insulation material

\begin{tabular}{cccc}
\hline & $\begin{array}{c}\text { Insulation } \\
\text { Paint }\end{array}$ & $\begin{array}{c}\text { Urethane } \\
\text { Foam }\end{array}$ & $\begin{array}{c}\text { Insulation Paint }+ \\
\text { Urethane Foam }\end{array}$ \\
\hline Thickness & $0.1 \mathrm{~mm}$ & $30 \mathrm{~mm}$ & $31 \mathrm{~mm}$ \\
\hline
\end{tabular}

Appearance

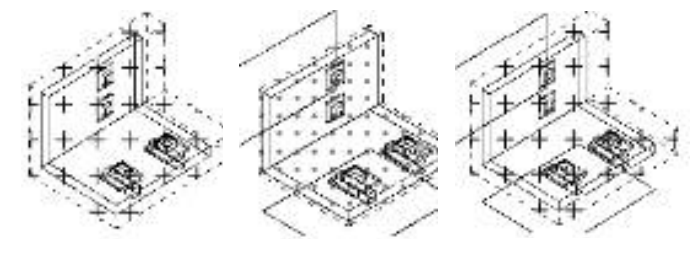

When simulated with the conditions shown in Table 3, the fastener covered with both insulation 
paint and urethane foam had the least heat loss. However, when compared by the insulation material, the insulation effect of the insulation paint was better than that of the urethane foam. Table 4 indicates the simulation results of the insulation material covered fastener, based on the annual heat loss of the non-insulated fastening unit.

Table 4. Comparison of heat loss (Covered)

\begin{tabular}{ccc}
\hline $\begin{array}{c}\text { Insulation } \\
\text { type }\end{array}$ & $\begin{array}{c}\text { Heat loss per } \\
\text { year (MJ) }\end{array}$ & $\begin{array}{c}\text { Comparison with } \\
\text { Non-insulated (\%) }\end{array}$ \\
\hline $\begin{array}{c}\text { Non-Insul } \\
\text { ation } \\
\text { Insulation } \\
\text { paint } \\
\text { Urethane } \\
\text { foam }\end{array}$ & 594.57 & - \\
$\begin{array}{c}\text { Insulation } \\
\text { paint }+ \\
\text { urethane } \\
\text { foam }\end{array}$ & 565.15 & -4.95 \\
\hline
\end{tabular}

\subsection{Review of the study trend}

From the two simulations above, it is apparent that insertion or covering of the insulation materials can improve the insulation effect of the fastening unit. However, the previously performed studies had many problems, and were not applied to the actual field.

When the fastening unit is inserted or covered with organic insulation material, problems occur in the event of fire. Inorganic insulation material is hard to construct in an airtight manner, and the insulation material is likely to corrode and generate mold due to the condensation that occurs when the air flows in through the gap.

In addition, as mentioned in the study objective, the strength of urethane is not sufficient, and when the fastening unit is inserted or covered with urethane, it can wear down depending on the wind load and the bolt tightening strength, making it an impractical insulation material from the structural view point. When the fastening unit is covered with urethane, the insulation thickness is over $30 \mathrm{~mm}$, making it impossible to use at the actual field.

In light of this study trend, further active studies on insulated fastening units that can be applied to the field should be required as there is currently a lack of practical studies in this area.

\section{Summary of the experiment}

To minimize condensation and thermal bridge of the designed fastening unit, insulation effect was evaluated after coating the insulation part with vibration-proof rubber and silicon. (Figures 3, 4 and 5) $[9,10]$

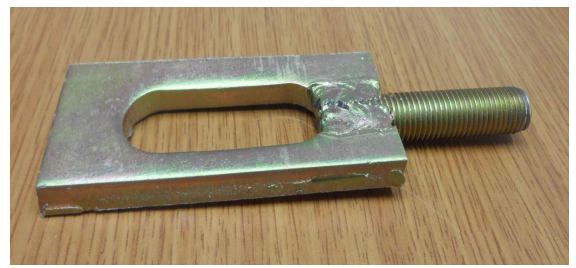

Figure 3. Non-insulated Connection Component

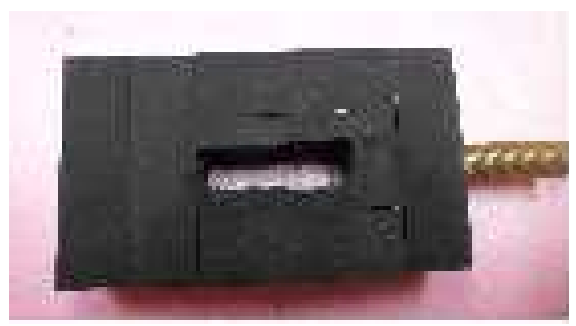

Figure 4. Connection Component coated with Rubber Insulation

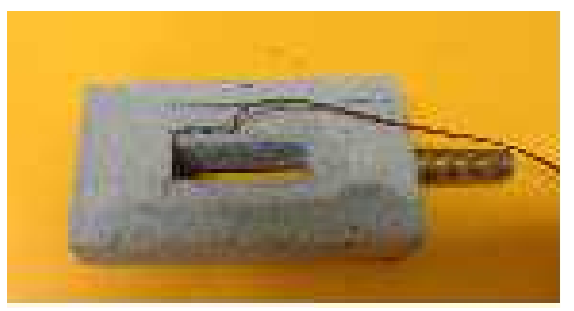

Figure 5. Connection Component coated with Silicon Insulation 


\subsection{Experimental factors}

To compare insulation effects, the fastening units were tested in insulated and non-insulated states. The fastening units were coated in $0.5 \mathrm{~cm}$ and $1.0 \mathrm{~cm}$ thickness respectively, with the vibration-proof rubber and the silicon. In addition, the temperature difference between the indoor air and the outdoor air was set at $30^{\circ} \mathrm{C}$ and $40^{\circ} \mathrm{C}$, respectively. The experimental factors and its levels are indicated in Table 5 .

Table 5. Experimental Factor

\begin{tabular}{cc}
\hline Experimental Factor & Experiment Level \\
\hline Insulation & Rubber \\
& Silicon \\
Insulation thickness & $0.5 \mathrm{~cm}$ \\
& $1.0 \mathrm{~cm}$ \\
Temperature Differential & $30^{\circ} \mathrm{C}\left(25^{\circ} \mathrm{C}-5^{\circ} \mathrm{C}\right)$ \\
& $40^{\circ} \mathrm{C}\left(35^{\circ} \mathrm{C}-5^{\circ} \mathrm{C}\right)$ \\
\hline
\end{tabular}

\subsection{Properties of insulation material}

The properties of vibration-proof rubber and silicon, which was used as insulation material in the experiment, are shown in Table 6.

Table 6. Properties of insulation material

\begin{tabular}{ccc}
\hline & Rubber & Silicon \\
\hline $\begin{array}{c}\text { Density } \\
\text { (Specific Gravity) } \\
\text { Thermal } \\
\text { Conduction Rate }\end{array}$ & $1621.9 \mathrm{~kg} / \mathrm{m}^{3}$ & $1483.4 \mathrm{~kg} / \mathrm{m}^{3}$ \\
Specific Heat & $0.1715 \mathrm{~W} / \mathrm{m} \cdot \mathrm{k}$ & $0.2214 \mathrm{~W} / \mathrm{m} \cdot \mathrm{k}$ \\
\hline
\end{tabular}

\subsection{Devices used in the experiment}

The infrared thermal camera and the data logger that had CC thermocouple as temperature sensor were used to measure the temperature. The specifications of the devices used in the experiment are indicated in Table 7 and 8.
Table 7. Infrared thermal camera

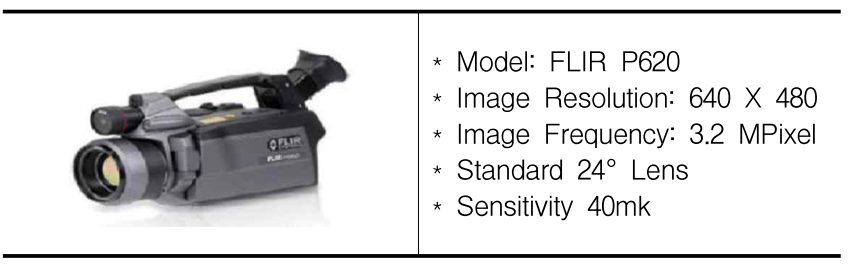

Table 8. Data logger

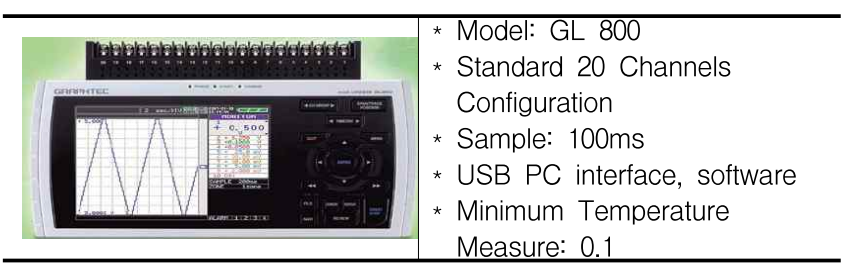

\subsection{Experimental contents}

The experiment was based on KS F 2277. To experiment the thermal transmittance, each end of the opening had to be blocked using the heating box, but the thermal transmittance could not be measured in this experiment due to the slab of the specimen connected to the panel (fire-resistant, lightweight inorganic composite foam material) that measures high temperature. Thus, it was substituted by attaching 5 OC thermocouples respectively on the surface of the high-temperature and the low-temperature panels to measure the surface temperature (Figures 8 and 9). The shape of the specimen that was installed in the thermal transmittance laboratory is shown in Figure 6, and Figures 7-9 indicate the points of temperature measurement in the experiment.

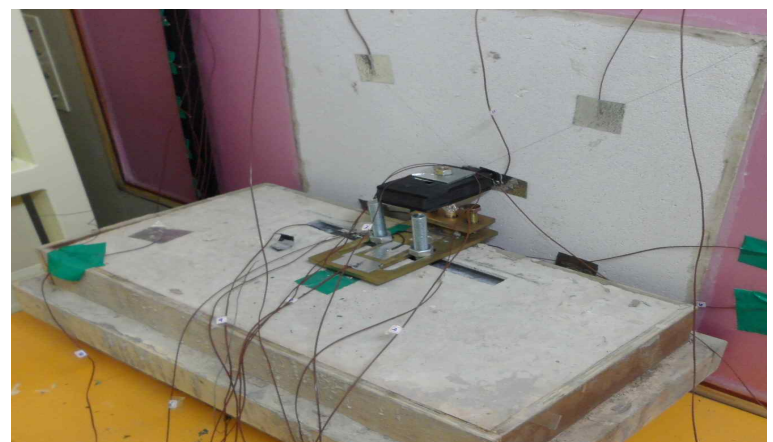

Figure 6. Specimen connecting Panel with Slab by Fastening Unit (Front) 


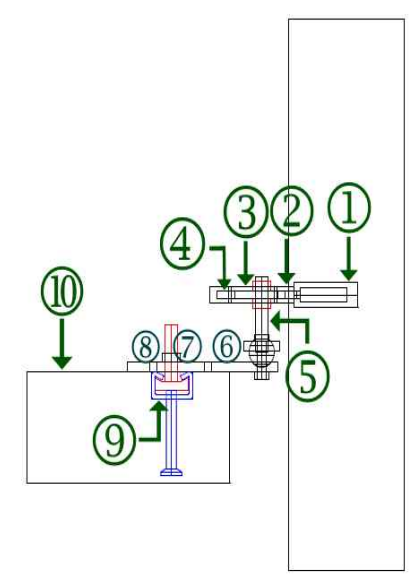

Figure 7. Points of temperature measurement in the specimen (elevation)

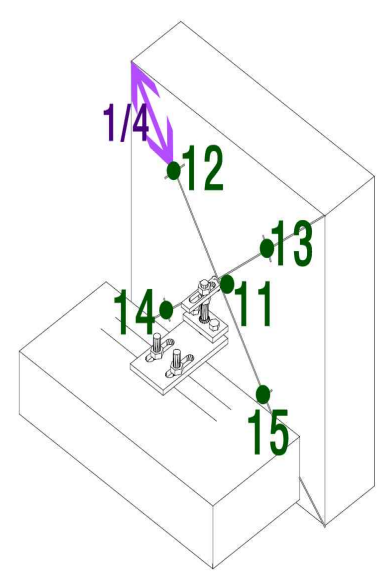

Figure 8. Points of temperature measurement: panel of high temperature side (in high temperature room)

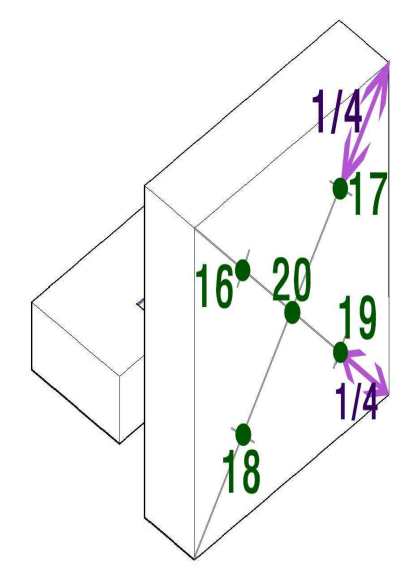

Figure 9. Points of temperature measurement: panel of low temperature side (in low temperature room)

Point 1 is where the fastening unit is inserted into the panel, and is the closest spot to the outdoor air (low-temperature room). Point 2 is where the fastening unit gets connected to the outdoor air, and Point 3 is where the temperature of the insulated part is measured. Point 4 is the closest spot to the indoor air (high-temperature room) among the Primary units. Point 5 is placed on the axis that connects the Primary and the Secondary unit. Points 6,7 , and 8 are the spots to check changes in the temperature of the Secondary unit, as it moves away from the panel to the indoor air direction. Point 9 is where the channel, which is embedded in the slab, connects the fastening unit, and Point 10 is attached to measure the surface temperature of the slab.

Instead of measuring the thermal transmittance, 5 measurement points were attached on each side of the panel where the fastening unit is constructed. They were placed in the $1 / 4$ distance away from each other diagonally and in the center (where the fastening unit is constructed), in order to measure the temperature distribution of the panel evenly. The measurement points of the panel are illustrated in Figures 8 and 9.

Since this study aims to evaluate the insulation performance of the fastening unit, comparative analysis was concentrated on the temperature difference between Point 2, where the fastening unit gets connected to the outdoor air, and Point 3 , where the temperature of the insulated part is measured, among the 20 measurement points of the specimen.

\subsection{Experimental methods}

The experiment was performed using the thermal transmittance laboratory equipment in Cheonan Engineering College at Kongju University to evaluate the thermal flow condition and the insulation performance of the specimen. According 
to the KS F 2277, the opening of the middle wall is $1500 \mathrm{~mm} \times 1500 \mathrm{~mm}$ in size and $2200 \mathrm{~mm}$ in thickness. The laboratory is $2800 \mathrm{~mm}$ high, and its floor plan is shown in Figure 10. (1) is the location of the air cooler in the low-temperature room, and the cold air was set to come out at a height of about $1600 \mathrm{~mm}$. (2) and (3) are the sticks set to measure the temperature distribution inside the experimental equipment. (4) is where the slab of the specimen is located. (5) is the location of the heater in the high-temperature room, and the hot air was set to come out at a height of about $500 \mathrm{~mm}$. (6) is the operating system of the thermal transmittance laboratory equipment installed on the exterior wall of the laboratory.

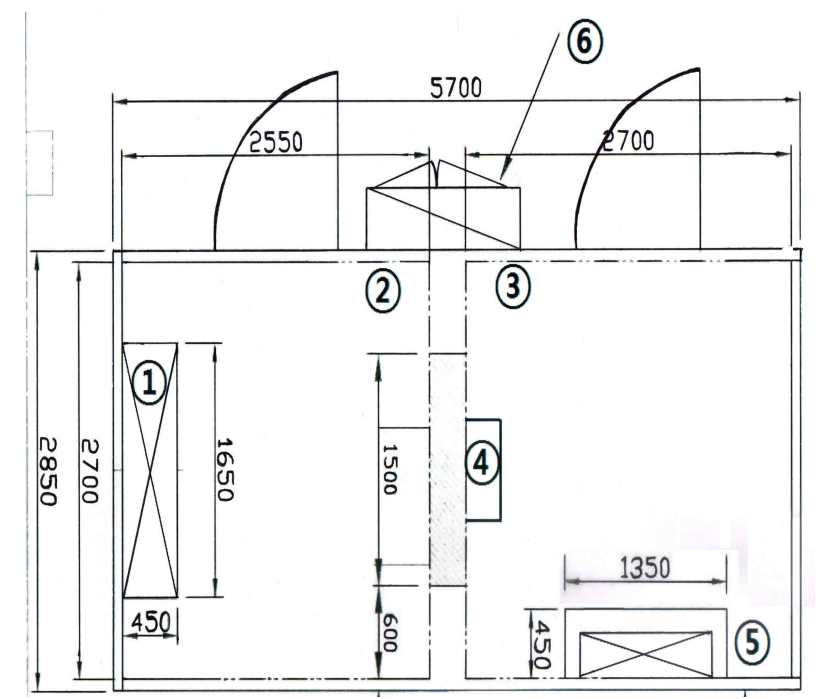

Figure 10. The Floor Plan of the Laboratory Equipment for Heat Transmission Coefficient

The panel size of the specimen set at the opening is $600 \mathrm{~mm} \times 600 \mathrm{~mm}$, and the rest of the opening' s space excluding the panel is blocked using extruded polystyrene foam with the gaps finished with silicon caulking. This specimen consists of a slab where the fastening unit is fixed, a wall panel and a fastening unit for connection. The size of the specimen is shown in Table 9, and the design temperature is shown in Table 5.

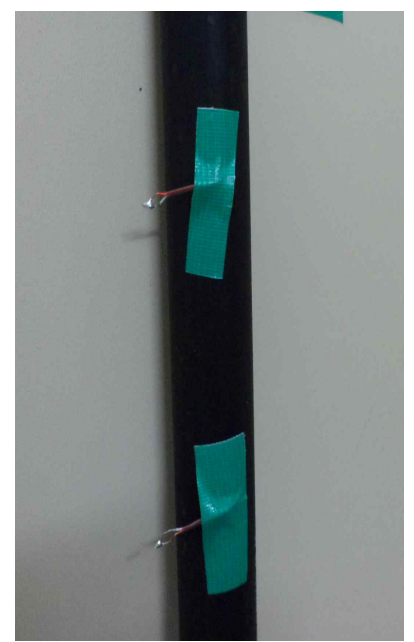

Figure 11. Stick sample for temperature distribution measurement

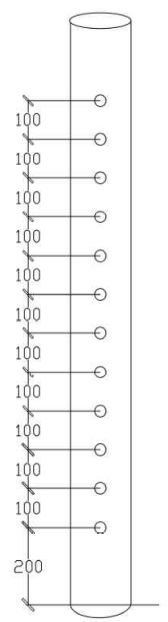

Figure 12. Stick for temperature distribution measurement
Table 6. Size of the specimen

\begin{tabular}{|c|c|}
\hline Division & Size \\
\hline Slab Size & $\begin{array}{c}600 \mathrm{~mm} \times 300 \mathrm{~mm} \times 200 \mathrm{~mm} \\
\text { (Width } \times \text { Length } \times \text { Height }) \\
- \text { Material: Concrete }\end{array}$ \\
\hline Panel Size & $\begin{array}{c}600 \mathrm{~mm} \times 600 \mathrm{~mm} \times 200 \mathrm{~mm} \\
\text { (Width } \times \text { Length } \times \text { Height }) \\
- \text { Material: Light Weight Concrete }\end{array}$ \\
\hline
\end{tabular}

\section{Experimental results and analysis}

To understand the air temperature distribution inside the thermal transmittance experimental equipment, thermocouples were attached to the sticks as shown in Figures 11 and 12, in order to measure the temperature of the high-temperature and the low-temperature rooms. 12 measurement points were set at $100 \mathrm{~mm}$ intervals starting from $200 \mathrm{~mm}$ above the floor, in order to understand the temperature distribution according to the height. Figure 11 shows the thermocouples connected to the stick through the holes drilled in the stick, while Figure 12 illustrates the locations of 12 thermocouples on the stick. 


\subsection{The temperature difference of thermal transmittance experimental equipment: $30^{\circ} \mathrm{C}$}

The following are the experimental results when the temperature difference was set at $30^{\circ} \mathrm{C}$. The temperature was measured every minute using the thermocouples, and stopped when the temperature was stabilized without any change for 30 minutes. The experiment time was about 6 hours when non-insulated fastening unit was used, but when insulation material coated fastening unit was used, the experiment time was about 12 hours.

\subsubsection{The temperature distribution of the laboratory}

The temperature distribution of the hightemperature and the low-temperature rooms is shown in Table 10. A total of 10 experiments were performed, and the temperature distribution gradually went up from the floor to the ceiling. The temperature differences stood at about $0.5-0$. $7^{\circ} \mathrm{C}$ in the high-temperature room and at about $0.3-04^{\circ} \mathrm{C}$ in the low-temperature room. The air temperature inside the laboratory is considered to have been very stable.

Table $10.30^{\circ} \mathrm{C}-$ Chart of temperature distribution in room

\begin{tabular}{ccc}
\hline $\begin{array}{c}\text { Type } \\
\text { Position }\end{array}$ & $\begin{array}{c}\text { High Temperature } \\
\text { Room }\end{array}$ & $\begin{array}{c}\text { Low Temperature } \\
\text { Room }\end{array}$ \\
\hline $20 \mathrm{~cm}$ & $24.1^{\circ} \mathrm{C}$ & $-4.6^{\circ} \mathrm{C}$ \\
$30 \mathrm{~cm}$ & $24.1^{\circ} \mathrm{C}$ & $-4.7^{\circ} \mathrm{C}$ \\
$40 \mathrm{~cm}$ & $24.3^{\circ} \mathrm{C}$ & $-4.8^{\circ} \mathrm{C}$ \\
$50 \mathrm{~cm}$ & $24.4^{\circ} \mathrm{C}$ & $-4.8^{\circ} \mathrm{C}$ \\
$60 \mathrm{~cm}$ & $24.3^{\circ} \mathrm{C}$ & $-4.8^{\circ} \mathrm{C}$ \\
$70 \mathrm{~cm}$ & $24.3^{\circ} \mathrm{C}$ & $-4.8^{\circ} \mathrm{C}$ \\
$80 \mathrm{~cm}$ & $24.3^{\circ} \mathrm{C}$ & $-4.8^{\circ} \mathrm{C}$ \\
$90 \mathrm{~cm}$ & $24.4^{\circ} \mathrm{C}$ & $-4.8^{\circ} \mathrm{C}$ \\
$100 \mathrm{~cm}$ & $24.4^{\circ} \mathrm{C}$ & $-4.9^{\circ} \mathrm{C}$ \\
$110 \mathrm{~cm}$ & $24.4^{\circ} \mathrm{C}$ & $-4.8^{\circ} \mathrm{C}$ \\
$120 \mathrm{~cm}$ & $24.6{ }^{\circ} \mathrm{C}$ & $-4.9^{\circ} \mathrm{C}$ \\
$130 \mathrm{~cm}$ & $24.6{ }^{\circ} \mathrm{C}$ & $-5.0^{\circ} \mathrm{C}$ \\
\hline
\end{tabular}

\subsubsection{Temperature distribution by insulation type}

1) Non-insulation

When non-insulated, the temperature difference between Point 2 (connected with the outdoor air) and Point 3 (insulated part) stood at about $1.0^{\circ} \mathrm{C}$.

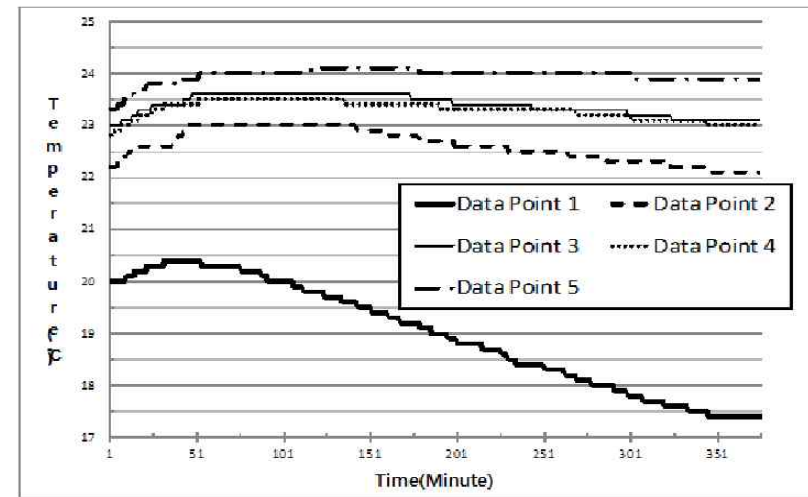

Figure 13. Chart of temperature distribution : non-insulation's Fastening Unit

2) Insulation layer: vibration-proof rubber $(0.5 \mathrm{~cm})$ When insulated with $0.5 \mathrm{~cm}$ thick vibration-proof rubber, the temperature difference between Points 2 and 3 was $2.2^{\circ} \mathrm{C}$. The temperature difference is $1.2^{\circ} \mathrm{C}$ higher than when non-insulated, due to the insulation effect of the $0.5 \mathrm{~cm}$ thick vibration-proof rubber. While it is beneficial for energy conservation, it is not enough to prevent condensation.

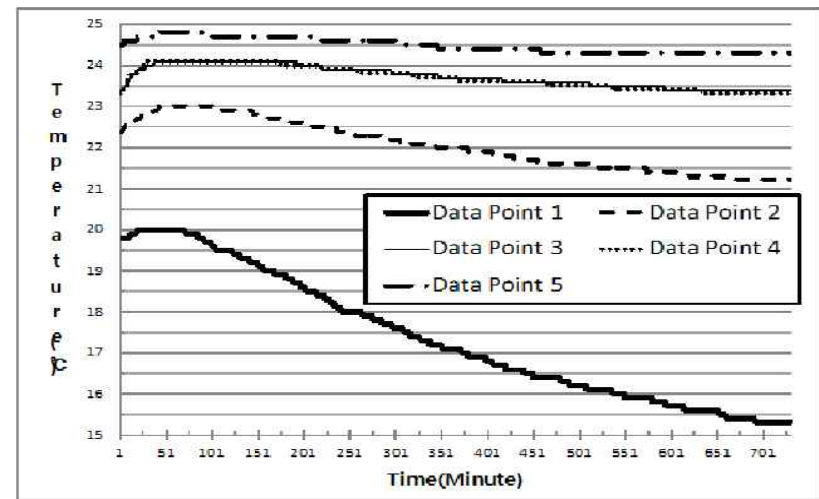

Figure 14. Chart of temperature distribution: rubber insulated fastening unit $\langle$ TK: $0.5 \mathrm{~cm}$ Type $>$

3) Insulation layer: vibration-proof rubber $(1.0 \mathrm{~cm})$ When insulated with $1.0 \mathrm{~cm}$ thick vibration-proof rubber, the temperature difference between Points 2 and 3 was $3.3^{\circ} \mathrm{C}$, which is $2.3^{\circ} \mathrm{C}$ higher than when 
non-insulated, and $1.1^{\circ} \mathrm{C}$ higher than when insulated with $0.5 \mathrm{~cm}$ thick vibration-proof rubber. It turns out that as the insulation layer gets thicker, the insulation effect increases proportionally.

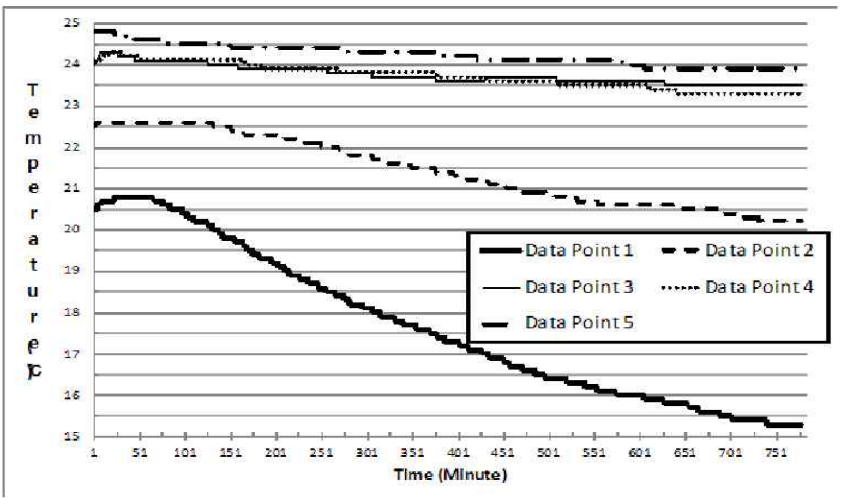

Figure 15. Chart of temperature distribution: rubber insulated fastening unit $\langle\mathrm{TK}: 1.0 \mathrm{~cm}$ Type $>$

4) Insulation layer: silicon $(0.5 \mathrm{~cm})$

When insulated with $0.5 \mathrm{~cm}$ thick silicon, the temperature difference between Points 2 and 3 was $2.8^{\circ} \mathrm{C}$, which was $1.8^{\circ} \mathrm{C}$ higher than when non-insulated. It is also $0.6^{\circ} \mathrm{C}$ higher than when insulated with $0.5 \mathrm{~cm}$ thick vibration-proof rubber.

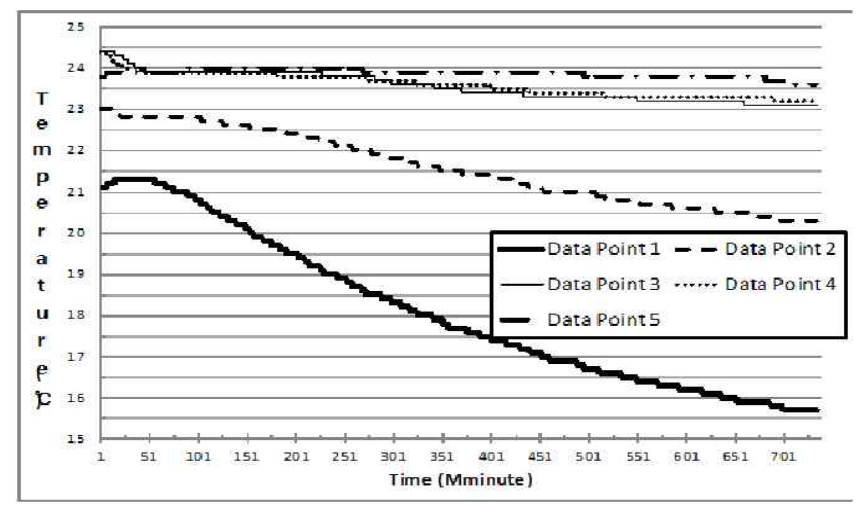

Figure 16. Chart of temperature distribution: silicon insulated fastening unit <TK: $0.5 \mathrm{~cm}$ Type $>$

5) Insulation layer: silicon (1.0cm)

When insulated with $1.0 \mathrm{~cm}$ thick silicon, the temperature difference between Points 2 and 3 was $2.9^{\circ} \mathrm{C}$, which was $1.9^{\circ} \mathrm{C}$ higher than when non-insulated, and $0.1^{\circ} \mathrm{C}$ higher than when insulated with $0.5 \mathrm{~cm}$ thick silicon. However, unlike the results of the vibration-proof rubber, thickness did not significantly affect the temperature difference.

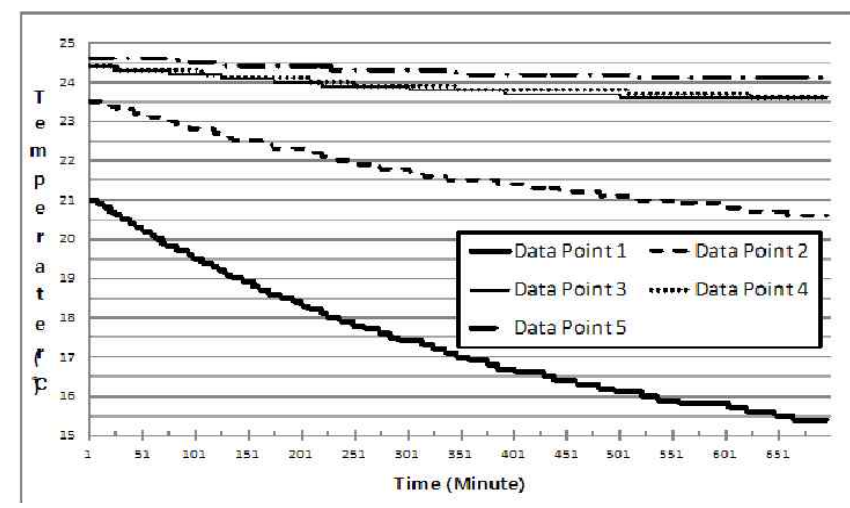

Figure 17. Chart of temperature distribution: silicon insulated fastening unit $\langle\mathrm{TK}: 1.0 \mathrm{~cm}$ Type $>$

\subsubsection{Temperature distribution of other parts of the specimen}

1) Temperature distribution of the Secondary fastening unit

Regardless of the experiment, the temperature distribution at Points 6-10 of the fastening was generally similar under the temperature below $25^{\circ} \mathrm{C}$ due to the influence of the high-temperature room. Table 11 indicates the temperature distribution of secondary fastening unit, channel and slab.

Table $11.30^{\circ} \mathrm{C}-$ Chart of temperature distribution: fastening unit

\begin{tabular}{cccccc}
\hline $\begin{array}{c}\text { Type } \\
\text { Data } \\
\text { Point }\end{array}$ & $\begin{array}{c}\text { Non- } \\
\text { Insulation }\end{array}$ & $\begin{array}{c}\text { Rubber } \\
\text { TK:0.5cm }\end{array}$ & $\begin{array}{c}\text { Rubber } \\
\text { TK:1.0cm }\end{array}$ & $\begin{array}{c}\text { Silicon } \\
\text { TK:0.5cm }\end{array}$ & $\begin{array}{c}\text { Silicon } \\
\text { TK:1.0cm }\end{array}$ \\
\hline 6 & $24.1^{\circ} \mathrm{C}$ & $24.6^{\circ} \mathrm{C}$ & $24.3^{\circ} \mathrm{C}$ & $24.1^{\circ} \mathrm{C}$ & $24.3^{\circ} \mathrm{C}$ \\
7 & $24.0^{\circ} \mathrm{C}$ & $24.6^{\circ} \mathrm{C}$ & $24.4^{\circ} \mathrm{C}$ & $24.1^{\circ} \mathrm{C}$ & $24.3^{\circ} \mathrm{C}$ \\
8 & $24.0^{\circ} \mathrm{C}$ & $24.6^{\circ} \mathrm{C}$ & $24.4^{\circ} \mathrm{C}$ & $24.2^{\circ} \mathrm{C}$ & $24.3^{\circ} \mathrm{C}$ \\
9 & $23.8^{\circ} \mathrm{C}$ & $24.6^{\circ} \mathrm{C}$ & $24.4^{\circ} \mathrm{C}$ & $23.8^{\circ} \mathrm{C}$ & $24.2^{\circ} \mathrm{C}$ \\
10 & $23.9^{\circ} \mathrm{C}$ & $24.7^{\circ} \mathrm{C}$ & $24.4^{\circ} \mathrm{C}$ & $24.9^{\circ} \mathrm{C}$ & $24.3^{\circ} \mathrm{C}$ \\
\hline
\end{tabular}


2) Temperature distribution of the Panel

Since the heater was very close to the lower part of the panel (Points 14 and 15), the temperature at the lower part of the panel was slightly higher than the upper part, but the temperature difference on the same panel was comparatively even, less than $1^{\circ} \mathrm{C}$. Table 12 indicates the temperature distribution of the panel during the experiment.

Table $12.30^{\circ} \mathrm{C}-$ Chart of temperature distribution: panel

\begin{tabular}{|c|c|c|c|c|c|}
\hline $\begin{array}{l}\text { Type } \\
\text { Data } \\
\text { Point }\end{array}$ & $\begin{array}{c}\text { Non- } \\
\text { Insulation }\end{array}$ & $\begin{array}{l}\text { Rubber } \\
\text { TK:0.5cm }\end{array}$ & $\begin{array}{l}\text { Rubber } \\
\text { TK:1.0cm }\end{array}$ & $\begin{array}{l}\text { Silicon } \\
\text { TK:0.5cm }\end{array}$ & $\begin{array}{l}\text { Silicon } \\
\text { TK:1.0cm }\end{array}$ \\
\hline 11 & $22.8^{\circ} \mathrm{C}$ & $22.1^{\circ} \mathrm{C}$ & $21.8^{\circ} \mathrm{C}$ & $22.1^{\circ} \mathrm{C}$ & $22.3^{\circ} \mathrm{C}$ \\
\hline 12 & $22.5^{\circ} \mathrm{C}$ & $21.7^{\circ} \mathrm{C}$ & $21.6^{\circ} \mathrm{C}$ & $21.7^{\circ} \mathrm{C}$ & $21.9^{\circ} \mathrm{C}$ \\
\hline 13 & $22.4^{\circ} \mathrm{C}$ & $21.7^{\circ} \mathrm{C}$ & $21.6^{\circ} \mathrm{C}$ & $21.6^{\circ} \mathrm{C}$ & $21.9^{\circ} \mathrm{C}$ \\
\hline 14 & $23.0^{\circ} \mathrm{C}$ & $22.5^{\circ} \mathrm{C}$ & $22.5^{\circ} \mathrm{C}$ & $22.5^{\circ} \mathrm{C}$ & $22.8^{\circ} \mathrm{C}$ \\
\hline 15 & $22.9^{\circ} \mathrm{C}$ & $22.5^{\circ} \mathrm{C}$ & $22.3^{\circ} \mathrm{C}$ & $22.3^{\circ} \mathrm{C}$ & $22.4^{\circ} \mathrm{C}$ \\
\hline 16 & $-2.7^{\circ} \mathrm{C}$ & $-2.4^{\circ} \mathrm{C}$ & $-3.0^{\circ} \mathrm{C}$ & $-2.6^{\circ} \mathrm{C}$ & $-2.6^{\circ} \mathrm{C}$ \\
\hline 17 & $-2.7^{\circ} \mathrm{C}$ & $-2.8^{\circ} \mathrm{C}$ & $-3.0^{\circ} \mathrm{C}$ & $-2.6^{\circ} \mathrm{C}$ & $-2.5^{\circ} \mathrm{C}$ \\
\hline 18 & $-2.1^{\circ} \mathrm{C}$ & $-2.1^{\circ} \mathrm{C}$ & $-2.7^{\circ} \mathrm{C}$ & $-2.4^{\circ} \mathrm{C}$ & $-2.2^{\circ} \mathrm{C}$ \\
\hline 19 & $-1.7^{\circ} \mathrm{C}$ & $-2.3^{\circ} \mathrm{C}$ & $-2.3^{\circ} \mathrm{C}$ & $-2.1^{\circ} \mathrm{C}$ & $-1.9^{\circ} \mathrm{C}$ \\
\hline 20 & $-2.4^{\circ} \mathrm{C}$ & $-2.5^{\circ} \mathrm{C}$ & $-2.8^{\circ} \mathrm{C}$ & $-2.5^{\circ} \mathrm{C}$ & $-2.4^{\circ} \mathrm{C}$ \\
\hline
\end{tabular}

\subsection{The temperature difference of thermal transmittance experimental equipment: $40^{\circ} \mathrm{C}$}

The following are the experimental results when the temperature difference between the high- and low-temperature rooms was set at $40^{\circ} \mathrm{C}$. The experimental method and the temperature measuring method are identical to that of the $30^{\circ} \mathrm{C}$ temperature difference. The experiment time was about 6 hours when non-insulated fastening unit was used, but when insulation material coated fastening unit was used, the temperature was stabilized after 5 8 hours had passed.

\subsubsection{Temperature distribution of the laboratory}

The temperature distribution of the high- and the low-temperature room is shown in Table 13.
The measuring method is identical to that of the $30^{\circ} \mathrm{C}$ temperature difference. The temperature difference between the highest and the lowest ends of the stick stood at about $1.1^{\circ} \mathrm{C} \sim 1.3^{\circ} \mathrm{C}$ in the high-temperature room, and at about $0.1^{\circ} \mathrm{C} \sim 0.3^{\circ} \mathrm{C}$ in the low-temperature room. In the high-temperature room, the upper part of the stick had higher temperature than the lower part. However, in the low-temperature room, the upper part of the stick had lower temperature than the lower part. This is because the air cooler is positioned at the upper part of the low-temperature room. Despite this fact, the temperature difference between the highest and the lowest ends of the stick was very slight, which indicates that the air temperature inside the laboratory was stable.

Table $13.40^{\circ} \mathrm{C}-$ Chart of temperature distribution in room

\begin{tabular}{ccc}
\hline $\begin{array}{c}\text { Type } \\
\text { Position }\end{array}$ & $\begin{array}{c}\text { High Temperature } \\
\text { Room }\end{array}$ & $\begin{array}{c}\text { Low Temperature } \\
\text { Room }\end{array}$ \\
\hline $20 \mathrm{~cm}$ & $33.9^{\circ} \mathrm{C}$ & $-4.6^{\circ} \mathrm{C}$ \\
$30 \mathrm{~cm}$ & $34.1^{\circ} \mathrm{C}$ & $-4.6^{\circ} \mathrm{C}$ \\
$40 \mathrm{~cm}$ & $34.3^{\circ} \mathrm{C}$ & $-4.7^{\circ} \mathrm{C}$ \\
$50 \mathrm{~cm}$ & $34.3^{\circ} \mathrm{C}$ & $-4.7^{\circ} \mathrm{C}$ \\
$60 \mathrm{~cm}$ & $34.2^{\circ} \mathrm{C}$ & $-4.7^{\circ} \mathrm{C}$ \\
$70 \mathrm{~cm}$ & $34.4^{\circ} \mathrm{C}$ & $-4.8^{\circ} \mathrm{C}$ \\
$80 \mathrm{~cm}$ & $34.4^{\circ} \mathrm{C}$ & $-4.8^{\circ} \mathrm{C}$ \\
$90 \mathrm{~cm}$ & $34.5^{\circ} \mathrm{C}$ & $-4.9^{\circ} \mathrm{C}$ \\
$100 \mathrm{~cm}$ & $34.5^{\circ} \mathrm{C}$ & $-5.0^{\circ} \mathrm{C}$ \\
$110 \mathrm{~cm}$ & $34.5^{\circ} \mathrm{C}$ & $-4.9^{\circ} \mathrm{C}$ \\
$120 \mathrm{~cm}$ & $34.9^{\circ} \mathrm{C}$ & $-5.0^{\circ} \mathrm{C}$ \\
$130 \mathrm{~cm}$ & $35.0^{\circ} \mathrm{C}$ & $-5.0^{\circ} \mathrm{C}$ \\
\hline
\end{tabular}

\subsubsection{Temperature distribution by insulation type}

1) Non-insulation

When non-insulated, the temperature difference between Point 2 (connected with the outdoor air) and Point 3 (insulated part) stood at about $2.1^{\circ} \mathrm{C}$. 


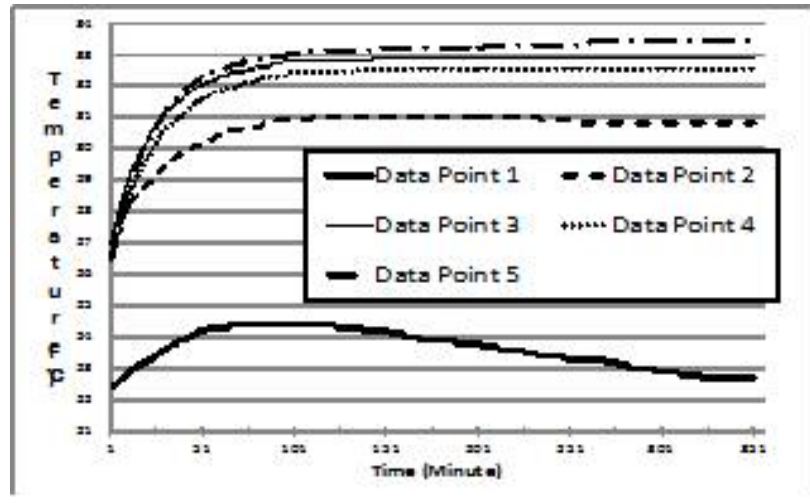

Figure 18. Chart of temperature distribution: non-insulated fastening unit

2) Insulation layer: vibration-proof rubber $(0.5 \mathrm{~cm})$ When insulated with $0.5 \mathrm{~cm}$ thick vibration-proof rubber, the temperature difference between Points 2 and 3 was $2.5^{\circ} \mathrm{C}$, which is $0.4^{\circ} \mathrm{C}$ higher than when non-insulated.

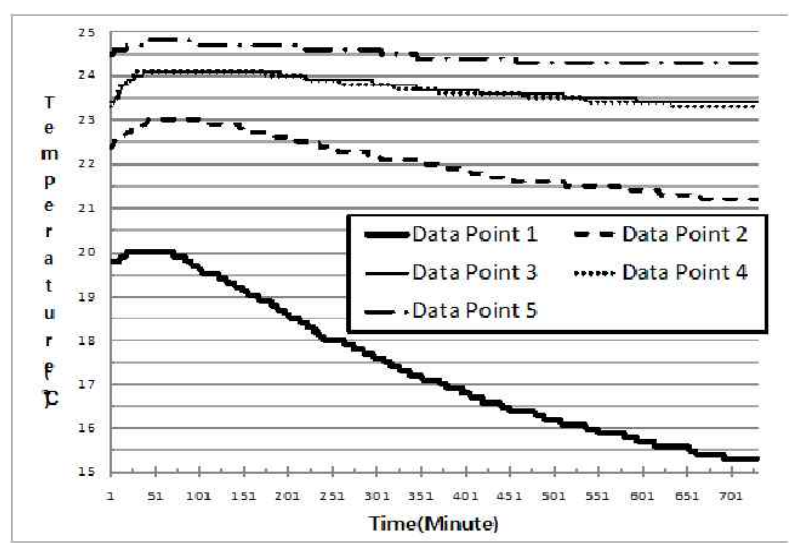

Figure 19. Chart of temperature distribution: rubber insulated fastening unit <TK: $0.5 \mathrm{~cm}$ Type $>$

3) Insulation layer: vibration-proof rubber $(1.0 \mathrm{~cm})$ When insulated with $1.0 \mathrm{~cm}$ thick vibration-proof rubber, the temperature difference between Points 2 and 3 was about $5.0^{\circ} \mathrm{C}$, which is $2.9^{\circ} \mathrm{C}$ higher than when non-insulated, and $2.5^{\circ} \mathrm{C}$ higher than when insulated with $0.5 \mathrm{~cm}$ thick vibration-proof rubber. Just like the $30^{\circ} \mathrm{C}$ temperature difference experiment, it seems that as the insulation layer gets thicker, the insulation effect increases proportionally. The temperature difference of the
$1.0 \mathrm{~cm}$ thick vibration-proof rubber insulation was the biggest of all the experiments. Although the temperature difference was not exactly proportional to the thermal conductivity of the insulation material, the thermal conductivity of the vibration-proof rubber is lower than that of the silicon, which is the main reason for the biggest temperature difference.

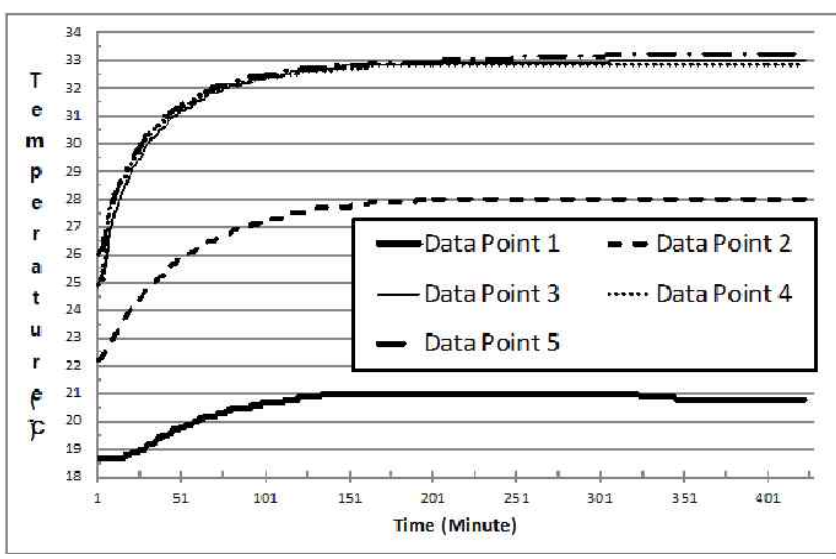

Figure 20. Chart of temperature distribution: rubber insulated fastening unit $\langle\mathrm{TK}: 1.0 \mathrm{~cm}$ Type $>$

4) Insulation layer: $0.5 \mathrm{~cm}$ silicon

When insulated with $0.5 \mathrm{~cm}$ thick silicon, the temperature difference between Points 2 and 3 was $3.9^{\circ} \mathrm{C}$, which is $1.8^{\circ} \mathrm{C}$ higher than when non-insulated. It is also $1.4^{\circ} \mathrm{C}$ higher than the vibration-proof rubber with the same thickness.

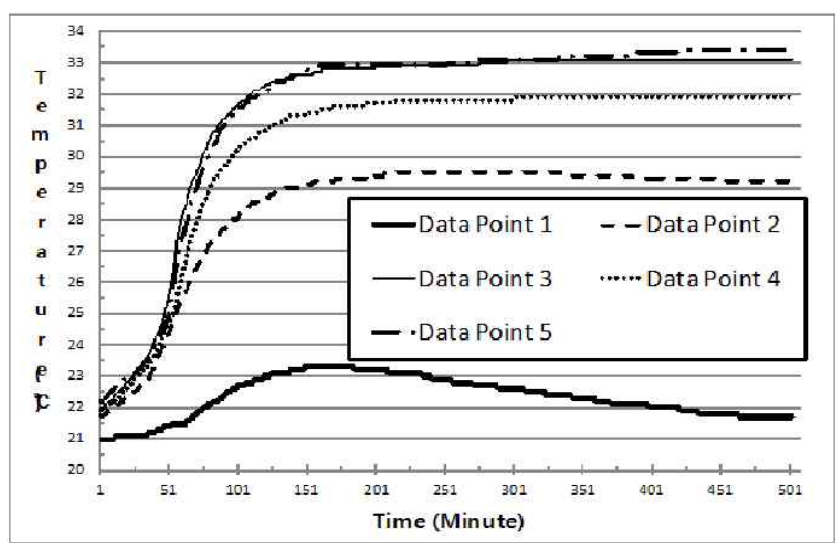

Figure 21. Chart of temperature distribution: silicon insulated fastening unit $\langle\mathrm{TK}: 0.5 \mathrm{~cm}$ Type $>$ 
5) Insulation layer: silicon $1.0 \mathrm{~cm}$

When insulated with $1.0 \mathrm{~cm}$ thick silicon, the temperature difference between Points 2 and 3 was $4.5^{\circ} \mathrm{C}$, which is $2.4^{\circ} \mathrm{C}$ higher than when non-insulated, and $0.6^{\circ} \mathrm{C}$ higher than when insulated with $0.5 \mathrm{~cm}$ thick silicon. Unlike the vibration-proof rubber, with which the temperature difference doubled according to the thickness, thickness did not affect the temperature difference significantly in silicon, which is similar to the experimental result at $30^{\circ} \mathrm{C}$ temperature. Silicon has a good insulation effect regardless of the thickness, but the thermal efficiency does not seem proportional to its thickness.

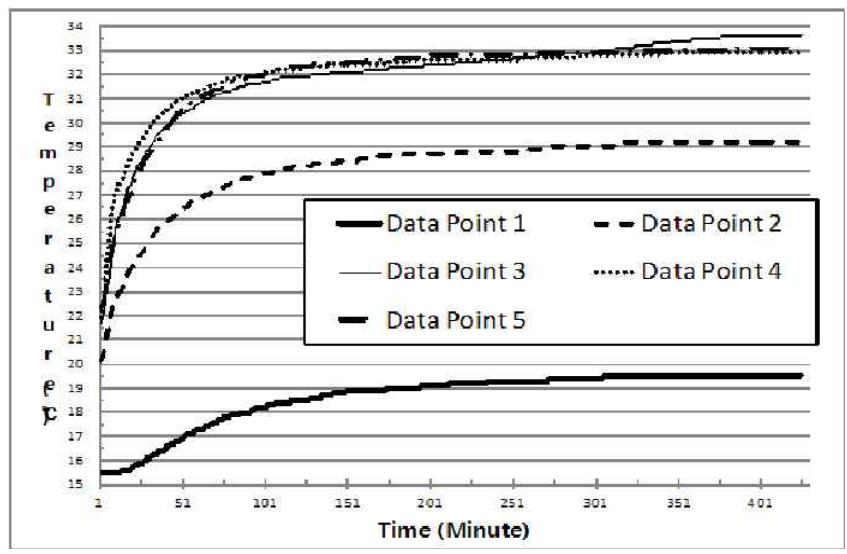

Figure 22. Chart of temperature distribution: silicon insulated fastening unit <TK: $1.0 \mathrm{~cm}$ Type $>$

\subsubsection{Temperature distribution of the panel and the fastening unit}

1) Temperature distribution of the fastening unit

Table 14 indicates the temperature distribution at Points $6-10$ of the fastening. There were slight temperature differences depending on the experiment. However, the general temperature of the slab-embedded channel (Point 9) and the slab (Point 10) was comparatively lower than that of the Secondary fastening unit (Points 6, 7, and 8). This seems to be because the specific heat of steel is lower than that of concrete, and thus it was affected more by the high-temperature room.

Table $14.40^{\circ} \mathrm{C}-$ Chart of temperature distribution: fastening unit

\begin{tabular}{cccccc}
\hline $\begin{array}{c}\text { Type } \\
\text { Data } \\
\text { Point }\end{array}$ & $\begin{array}{c}\text { Non- } \\
\text { Insulation }\end{array}$ & $\begin{array}{c}\text { Rubber } \\
\text { TK:0.5cm }\end{array}$ & $\begin{array}{c}\text { Rubber } \\
\text { TK:1.0cm }\end{array}$ & $\begin{array}{c}\text { Silicon } \\
\text { TK:0.5cm }\end{array}$ & $\begin{array}{c}\text { Silicon } \\
\text { TK:1.0cm }\end{array}$ \\
\hline 6 & $32.8^{\circ} \mathrm{C}$ & $32.4^{\circ} \mathrm{C}$ & $33.6^{\circ} \mathrm{C}$ & $33.3^{\circ} \mathrm{C}$ & $32.8^{\circ} \mathrm{C}$ \\
7 & $32.4^{\circ} \mathrm{C}$ & $32.1^{\circ} \mathrm{C}$ & $33.6^{\circ} \mathrm{C}$ & $33.0^{\circ} \mathrm{C}$ & $32.8^{\circ} \mathrm{C}$ \\
8 & $32.4^{\circ} \mathrm{C}$ & $32.0^{\circ} \mathrm{C}$ & $33.6^{\circ} \mathrm{C}$ & $32.9^{\circ} \mathrm{C}$ & $33.0^{\circ} \mathrm{C}$ \\
9 & $30.0^{\circ} \mathrm{C}$ & $29.5^{\circ} \mathrm{C}$ & $32.5^{\circ} \mathrm{C}$ & $31.3^{\circ} \mathrm{C}$ & $31.8^{\circ} \mathrm{C}$ \\
10 & $30.5^{\circ} \mathrm{C}$ & $30.2^{\circ} \mathrm{C}$ & $32.9^{\circ} \mathrm{C}$ & $31.8^{\circ} \mathrm{C}$ & $31.6^{\circ} \mathrm{C}$ \\
\hline
\end{tabular}

2) Temperature distribution of the Panel

Since the heater was located closer to Points 14 and 15 of the panel, the lower part of the panel had slightly higher temperature distribution than that of the upper part. However, the temperature difference of the measuring points located on the same side of the panel was less than $1^{\circ} \mathrm{C}$, and the temperature distribution of the panel was comparatively even. The temperature difference located on a panel was around $1^{\circ} \mathrm{C}$, and the temperature distribution was comparatively even. Table 15 indicates the temperature distribution of the panel during the experiment.

Table $15.40^{\circ} \mathrm{C}-$ Chart of temperature distribution: panel

\begin{tabular}{cccccc}
\hline $\begin{array}{c}\text { Type } \\
\text { Data } \\
\text { Point }\end{array}$ & $\begin{array}{c}\text { Non- } \\
\text { Insulation }\end{array}$ & $\begin{array}{c}\text { Rubber } \\
\text { TK:0.5cm }\end{array}$ & $\begin{array}{c}\text { Rubber } \\
\text { TK:1.0cm }\end{array}$ & $\begin{array}{c}\text { Silicon } \\
\text { TK:0.5cm }\end{array}$ & $\begin{array}{c}\text { Silicon } \\
\text { TK:1.0cm }\end{array}$ \\
\hline 11 & $31.4^{\circ} \mathrm{C}$ & $31.1^{\circ} \mathrm{C}$ & $30.4^{\circ} \mathrm{C}$ & $31.5^{\circ} \mathrm{C}$ & $30.1^{\circ} \mathrm{C}$ \\
12 & $30.8^{\circ} \mathrm{C}$ & $30.8^{\circ} \mathrm{C}$ & $30.1^{\circ} \mathrm{C}$ & $30.6^{\circ} \mathrm{C}$ & $29.6^{\circ} \mathrm{C}$ \\
13 & $30.6^{\circ} \mathrm{C}$ & $31.3^{\circ} \mathrm{C}$ & $30.1^{\circ} \mathrm{C}$ & $30.5^{\circ} \mathrm{C}$ & $29.6^{\circ} \mathrm{C}$ \\
14 & $31.7^{\circ} \mathrm{C}$ & $31.3^{\circ} \mathrm{C}$ & $31.2^{\circ} \mathrm{C}$ & $31.9^{\circ} \mathrm{C}$ & $31.0^{\circ} \mathrm{C}$ \\
15 & $31.0^{\circ} \mathrm{C}$ & $31.2^{\circ} \mathrm{C}$ & $31.0^{\circ} \mathrm{C}$ & $31.1^{\circ} \mathrm{C}$ & $30.2^{\circ} \mathrm{C}$ \\
16 & $-2.2^{\circ} \mathrm{C}$ & $-1.9^{\circ} \mathrm{C}$ & $-2.4^{\circ} \mathrm{C}$ & $-2.3^{\circ} \mathrm{C}$ & $-2.5^{\circ} \mathrm{C}$ \\
17 & $-2.5^{\circ} \mathrm{C}$ & $-1.9^{\circ} \mathrm{C}$ & $-2.4^{\circ} \mathrm{C}$ & $-2.1^{\circ} \mathrm{C}$ & $-2.6^{\circ} \mathrm{C}$ \\
18 & $-3.9^{\circ} \mathrm{C}$ & $-1.2^{\circ} \mathrm{C}$ & $-2.0^{\circ} \mathrm{C}$ & $-1.7^{\circ} \mathrm{C}$ & $-2.3^{\circ} \mathrm{C}$ \\
19 & $-3.2^{\circ} \mathrm{C}$ & $-0.8^{\circ} \mathrm{C}$ & $-1.6^{\circ} \mathrm{C}$ & $-1.1^{\circ} \mathrm{C}$ & $-1.8^{\circ} \mathrm{C}$ \\
20 & $-2.9^{\circ} \mathrm{C}$ & $-1.5^{\circ} \mathrm{C}$ & $-1.8^{\circ} \mathrm{C}$ & $-1.9^{\circ} \mathrm{C}$ & $-2.0^{\circ} \mathrm{C}$ \\
\hline
\end{tabular}




\section{Experimental considerations}

Table 16 indicates the temperature differences between Points 2 and 3 of a total of 10 experiment results.

Table 16. Temperature difference at Points 2 and 3

\begin{tabular}{|c|c|c|c|c|c|c|}
\hline \multirow{2}{*}{$\begin{array}{l}\text { Temperatur } \\
\text { e difference }\end{array}$} & \multicolumn{3}{|c|}{$30^{\circ} \mathrm{C}$} & \multicolumn{3}{|c|}{$40^{\circ} \mathrm{C}$} \\
\hline & No.2 & No.3 & $\begin{array}{c}\text { Differe } \\
\text { nce }\end{array}$ & No.2 & No.3 & $\begin{array}{c}\text { Differe } \\
\text { nce }\end{array}$ \\
\hline $\begin{array}{c}\text { Non- } \\
\text { Insulation }\end{array}$ & $22.1^{\circ} \mathrm{C}$ & $23.1^{\circ} \mathrm{C}$ & $1.0^{\circ} \mathrm{C}$ & $30.8^{\circ} \mathrm{C}$ & $32.9^{\circ} \mathrm{C}$ & $2.1^{\circ} \mathrm{C}$ \\
\hline $\begin{array}{l}\text { Rubber } \\
\text { TK:0.5cm }\end{array}$ & $21.2^{\circ} \mathrm{C}$ & $23.4^{\circ} \mathrm{C}$ & $2.2^{\circ} \mathrm{C}$ & $30.1^{\circ} \mathrm{C}$ & $32.6^{\circ} \mathrm{C}$ & $2.5^{\circ} \mathrm{C}$ \\
\hline $\begin{array}{c}\text { Rubber TK: } \\
1.0 \mathrm{~cm}\end{array}$ & $20.2^{\circ} \mathrm{C}$ & $23.5^{\circ} \mathrm{C}$ & $3.3^{\circ} \mathrm{C}$ & $28.0^{\circ} \mathrm{C}$ & $33.0^{\circ} \mathrm{C}$ & $5.0^{\circ} \mathrm{C}$ \\
\hline $\begin{array}{c}\text { Silicon TK: } \\
0.5 \mathrm{~cm}\end{array}$ & $20.3^{\circ} \mathrm{C}$ & $23.1^{\circ} \mathrm{C}$ & $2.8^{\circ} \mathrm{C}$ & $29.2^{\circ} \mathrm{C}$ & $33.1^{\circ} \mathrm{C}$ & $3.9^{\circ} \mathrm{C}$ \\
\hline $\begin{array}{c}\text { Silicon TK: } \\
1.0 \mathrm{~cm}\end{array}$ & $21.6^{\circ} \mathrm{C}$ & $23.6^{\circ} \mathrm{C}$ & $2.9^{\circ} \mathrm{C}$ & $29.1^{\circ} \mathrm{C}$ & $33.6^{\circ} \mathrm{C}$ & $4.5^{\circ} \mathrm{C}$ \\
\hline
\end{tabular}

Table 17 shows the values according to the psychometric charts. By applying the indoor temperature (DBT) and relative humidity (RH), one can determine whether condensation takes place based on the dew point temperature.

The temperature in the low-temperature room was measured as far as $-5^{\circ} \mathrm{C}$ due to the performance restriction of the thermal transmittance experimental equipment. However, when the experiment result is compared with the assumption that outdoor and indoor temperatures in the winter are $-20^{\circ} \mathrm{C}$ and $20^{\circ} \mathrm{C}$, respectively, though not always proportional, it is possible to predict whether dew condensation will take place or not.

Suppose the value of the experiment result was $15^{\circ} \mathrm{C}$ lower than the actual test temperature, when the outdoor temperature was set at $-20^{\circ} \mathrm{C}$, which is the indoor-outdoor temperature condition for general dew condensation determination. The temperature at Point 2 is estimated to be $5^{\circ} \mathrm{C}-6^{\circ} \mathrm{C}$, when experimented under the temperature difference of $30^{\circ} \mathrm{C}$, and the dew condensation occurs when the indoor temperature is higher than $18^{\circ} \mathrm{C}$, and the relative humidity is over $45 \%$. Likewise, when experimented under the temperature difference of $40^{\circ} \mathrm{C}$ and applying identical conditions, the dew condensation is much more likely to occur when the indoor temperature is higher than $22^{\circ} \mathrm{C}$, and the relative humidity is over 55\%. Therefore, it is considered that when there is a temperature difference of more than $2^{\circ} \mathrm{C}$ $-5^{\circ} \mathrm{C}$ caused by using anchor insulation, dew condensation can be prevented, even if the indoor temperature increases by more than $3^{\circ} \mathrm{C}$.

Table 17. Each relative humidity at dew point temperature

\begin{tabular}{cccccc}
\hline $\mathrm{DBT} / \mathrm{RH}$ & $40 \%$ & $45 \%$ & $50 \%$ & $55 \%$ & $60 \%$ \\
\hline $17{ }^{\circ} \mathrm{C}$ & 3.3 & 5.0 & 6.5 & 7.9 & 9.2 \\
$18^{\circ} \mathrm{C}$ & 4.2 & 5.9 & 7.4 & 8.8 & 10.1 \\
$19^{\circ} \mathrm{C}$ & 5.1 & 6.8 & 8.4 & 9.8 & 11.1 \\
$20^{\circ} \mathrm{C}$ & 6.0 & 7.7 & 9.3 & 10.7 & 12.0 \\
$21{ }^{\circ} \mathrm{C}$ & 6.9 & 8.6 & 10.2 & 11.6 & 12.9 \\
$22{ }^{\circ} \mathrm{C}$ & 7.8 & 9.5 & 11.1 & 12.6 & 13.9 \\
$23{ }^{\circ} \mathrm{C}$ & 8.7 & 10.4 & 12.0 & 13.5 & 14.8 \\
$24{ }^{\circ} \mathrm{C}$ & 9.6 & 11.3 & 12.9 & 14.4 & 15.8 \\
$25{ }^{\circ} \mathrm{C}$ & 10.5 & 12.3 & 13.9 & 15.3 & 16.7 \\
\hline
\end{tabular}

\subsection{Conclusion}

Through the experiment and in consideration of the above, the following conclusion can be drawn.

1) Although there was somewhat loss of energy even when the developed fastening unit system was insulated, it showed that condensation can be prevented, except in the extreme circumstances of winter.

2) Suppose the outdoor temperature in winter is $-20^{\circ} \mathrm{C}$ and the indoor temperature $20^{\circ} \mathrm{C}$, the temperature of the fastening area in the insulated part was about $18^{\circ} \mathrm{C}$, which is higher than the dew condensation temperature, and condensation was unlikely to be formed. 
3) In the general indoor state of the winter season, the circumstance of indoor temperature at $22^{\circ} \mathrm{C}$ and relative humidity at $55 \%$ can often be seen. Even under the reference temperature, the situation where the temperature and the humidity increase much higher in each part occurs. Considering these circumstances, insulation is considered to be needed.

4) When the temperature difference of the experimental equipment was $30^{\circ} \mathrm{C}$, the maximum temperature difference between the non-insulated and the insulated was $3.3^{\circ} \mathrm{C}$. When the temperature difference of the experimental equipment was $40^{\circ} \mathrm{C}$, the maximum temperature difference was $5.0^{\circ} \mathrm{C}$. Therefore, the condensation can be prevented.

\section{References}

1. Lee MW, Lee SW, Yeo MS, Song SY, Kim GW. A Study on the Construction Detail of Joints for Stone Panel Curtain Wall Considering the Prevention of Condensation. Journal of Architectural Institute of Korea. 2006 Apr;22(4):277-84.

2. Song SY, Kang KY, Yeo MS, Kim GW. Influence of Damaged Inside Finish Material for Insulation on the Condensation and Efficient Finish Material to Prevent Interstitial Condensation in Curtain Wall System. Journal of Architectural Institute of Korea. 2006 Aug;22(8):241-49.

3. Lee YG, Lee SH, Lee SY. Effect of Components Assembly and Sizing on the Thermal Performance of Windows. Journal of Architectural Institute of Korea. 2006 Jul;22(7):215-22.

4. Song SY, Goo BK, Seok HT. Performance Evaluation of the Various Insulation Schemes for Fastening Unit in Aluminum Curtain Wall System of Residential Complex. Academic Journal of Architectural Institute of Korea . 2006 Oct;26(1):609-12.

5. Kang SH, Goo BK, Joo SK, Song SY. Energy Performance and Economical Efficiency Evaluation of the Insulated Curtain Wall Anchoring Unit. Journal of Architectural Institute of Korea. 2003 Dec;19(12):279-86.

6. Song SY, Seok HT, Goo BK, Kim YJ. A Study on the Energy
Performance Improvement of Aluminum Curtain Wall Fastening Unit for Residential Complex by Insulation Coating. Journal of Architectural Institute of Korea. 2006 Feb;22(2):251-58.

7. Koo SY, Ku HY, Yeo MS, Kim GW. Thermal Performance of Opaque Part of the Curtain walls in Buildings. Journal of Architectural Institute of Korea. 2008 Oct;28(1):559-62.

8. Lee MJ, Lee SW, Yeo MS, Kim GW. An Experimental Study on Insulation and Preventing Condensation Performance of Ventilated Curtain Wall. Summer Academic Journal of Air-Conditioning and Refrigeration Engineering of Korea. 2006 Jun;18(1):1081-86.

9. Kim BJ, Kim KA, Park JM. Insulation Method and Performance Evaluation for Fastening Unit of ALC Pannel-Curtain wall. Proceedings of the Korea Institute of Building Construction; 2011 May 20; Dong-Eui University. Seoul (Korea): the Korea Institute of Building Construction; 2011. p. 107-10.

10. Kim BJ, Kim JM, Jung DK, Kim PJ, Lee SU, Seo MS. [An Experiment of Building Materials in Pictures]. 1st edition. Seoul (Korea): Kimoondang; 2006. 201 p. Korean. 